\title{
Оборудованные әкологические тропы Мурманской области как ресурс для развития экотуризма
}

\section{Грушенко Э.Б.}

Институт экономических проблем им. Г.П. Лузина ФИЦ КНЦ РАН, Аnатиты, grushenko.eduard@mail.ru

Аннотация. В статье дается обзор наиболее обустроенных и известных экологических троп на территории Мурманской области как ресурса для устойчивого развития экотуризма с целью охраны природы и экологического просвещения населения. На Кольском Севере основной акцент сделан на создании и обустройстве экологических троп и пешеходных маршрутов на особо охраняемых природных территориях (природных заповедников, ботанических садов и заказников) и туристско-рекреационных территориях населенных пунктов с пригородной зоной отдыха.

Ключевые слова: экологическая тропа, Мурманская область, экологический туризм, информационные стенды, заповедник, пешеходный маршрут, туристы, природа.

\section{Equipped ecological trails of the Murmansk region as a resource for the development of ecotourism}

\author{
Grushenko E.B. \\ Institute of Economic Problems. G.P. Luzin FIZ KSC RAS, Apatity, grushenko.eduard@mail.ru
}

\begin{abstract}
The article provides an overview of the most well-established and well-known ecological trails on the territory of the Murmansk region as a resource for the sustainable development of ecotourism in order to protect nature and environmental education of the population. In the Kola North, the main emphasis is placed on the creation and arrangement of ecological paths and pedestrian routes in specially protected natural areas (natural reserves, botanical gardens and reserves) and tourist and recreational areas of settlements with a suburban recreation area.
\end{abstract}

Key words: ecological path, Murmansk region, ecological tourism, information stands, nature reserve, walking route, tourists, nature.

Приоритетным видом туризма в Мурманской области признан экологический туризм. Экотуризм целесообразно развивать на особо охраняемых природных территориях (ООПТ) с целью регулирования и учета потока туристов.

В последнее время все чаще употребляется термин «экологическая тропа», «экотропа». Основная идея экотропы, прежде всего, состоит в экологическом обучении и воспитании тех, кто посещает охраняемые природные территории, в охране природы, а также в регуляции потока посетителей в относительно безопасные для природы направления (Чижова, 2011).

Традиционно экотропы прокладываются в рекреационных зонах национальных и природных парков, заповедников, заказников, а также и на неохраняемых территориях: в городских лесопарках, в пригородной зоне отдыха и т. д. Для создания системы экотроп необходимо соблюдать три главных критерия: привлекательность, доступность, информативность (Чижова, 1997).

Создание экологических троп выступает одним из главных компонентов экотуризма на ООПТ. Экотропы играют важную роль для регулирования допустимых нагрузок на охраняемые природные территории.

Чиновникам Минприроды необходимо разработать стандарт обустройства экологической тропы (маршрута) в ООПТ - что на нём должно быть (указатели, мостики, ограждение опасных мест, места привалов и ночлегов с туалетами, кострищем, навесами, мусоросборниками и др.). На полностью обустроенном маршруте, соответствующем стандарту, можно было бы устанавливать плату за посещение.

В Мурманской области в настоящее время обустроено в разных уголках региона 16 экологических троп. Девять из них проложены на ООПТ, больше всего (5 троп) - в Лапландском заповеднике. Три экотропы созданы на территории населенных пунктов. 
В Мурманске в 2018 г. был открыт первый экологический образовательный пешеходный маршрут вокруг Семеновского озера протяженностью 5 км. Для экологического просвещения активисты установили по пути экотропы знаки и стенды с информацией о местных природно-ландшафтных достопримечательностях и о необходимости бережного отношения к природе. В районе Семеновского озера можно увидеть сразу несколько природных зон: тундру, лесотундру, болота.

В одном из самых труднодоступных для туристов заповедников России, расположенном целиком в приграничной зоне, - природном заповеднике «Пасвик», обустроен пешеходный экскурсионный маршрут. Экологическая тропа ведет на остров Валаама к дому - музею норвежского орнитолога Ханса Сконнинга. С помощью волонтеров Кольской ГМК реконструирован дом-музей, была обустроена экотропа с возведением смотровой орнитологической вышки. «Пасвик» - это настоящий природный музей под открытым небом, здесь сохранились самые северные коренные сосновые леса в Европе. В перспективе возможно реализовать идею появления международной экологической тропы, проходящей по территории трех стран трансграничной территории Европарка «Пасвик-Инари» (Сайт заповедника «Пасвик», 2018).

Экологическая тропа в окрестностях арктического поморского села Териберка была организована во время фестиваля «Териберка. Новая жизнь» и ведет на птичий базар на берегу Баренцева моря. Тропа знакомит с уникальной экосистемой арктической тундры. Необходимо дальнейшее обустройство экотропы с упорядочением расстановки информационных стендов, установленных на маршруте довольно бессистемно и наложением деревянных настилов через болотистую местность. К началу пешеходного маршрута должны быть установлены указатели в жилой части Териберки, так как найти тропу самостоятельно, которая начинается в нескольких километрах к северо-востоку от поселка, в настоящее время довольно проблематично.

Самые известные обустроенные экологические тропы Кольского Севера проложены в Лапландском заповеднике. В заповеднике за последние два года стало больше пешеходных маршрутов, на которых ведутся эколого-просветительские экскурсии. Появились новые объекты показа: визит-центр, туристско-информационный центр (ТИЦ) и терем Деда Мороза.

Среди наиболее востребованных маршрутов - экотропа к старой усадьбе вдоль озера, тропа на гору Ельнюн, познавательная тропа «Лесная почемучка», пешеходный маршрут на смотровую площадку над ручьем Ельявруай. Новая тропа, оборудованная в 2017 г., протяженностью 3.5 км, проложена по берегу Чунозера и ведет к месту, где в 1930-м располагался первый кордон Лапландского заповедника, где начиналась его история. На тропе проложены деревянные настилы, оборудованы подъемы и спуски, места для отдыха и обзорные площадки, установлены информационные стенды и биотуалеты. Важно, что экотропа стала доступней и для малоподвижных людей с ограниченными возможностями здоровья. По дороге путешественники получают информацию об особенностях северной природы, смене растительных поясов, повадках животных.

Компания «Норникель» активно участвовала в создании экотроп по двум направлениям: корпоративное волонтерство и программе «Мир новых возможностей». Кольская ГМК выделила около 5 млн. рублей выигранного гранта на создание пешеходных маршрутов. Ключевым мероприятием экомарафона стал экологический слёт, когда волонтеры помогли оборудовать смотровую площадку и установили 20 информационных щитов вдоль экотроп. Основной целью проекта является экологическое воспитание, повышение культуры отношения к природе (Калинина, 2017).

Инновационный проект «Познавательная тропа «Лесная почемучка» - часть этой программы: на интерактивном маршруте появились скульптуры животных, птиц, малые архитектурные формы и информационные щиты. В дальнейшем будут установлены еще несколько скульптур, запланировано освещение тропы, в процессе завершения - создание Лаборатории Бабы-яги и Колодца знаний.

Экологическая тропа «Нижняя Чуна - Чунозерская усадьба» длиной 5 км начинается от кордона ТИЦ Нижняя Чуна (официальный въезд в заповедник) на Федеральной трассе «Кола» (1221 км) и ведет к Чунозерской усадьбе заповедника, где можно посетить два исторических музея, визитцентр. По маршруту маркированной тропы можно посетить саамский погост «Сийт», дендрарий, 
стоянки для отдыха, смотровые площадки, место для наблюдения за птицами «Глухариную горку» (Сайт Лапландского природного заповедника, 2018).

Восхождение на гору Ельнюн-ІІ высотой 590 м. Данный маршрут протяженностью около 3 км был заложен еще в 30 -е годы прошлого века и летом пользуется большой популярностью. Для удобства посетителей в зимнее время заповедник закупил специальное снаряжение - снегоступы. Данный маршрут интересен тем, что при подъеме на гору можно наглядно наблюдать высотную смену растительных поясов - тайгу, лесотундру и тундру. С вершины горы открывается панорамный вид на Чунозеро.

Сейчас территорию Лапландского заповедника посещает зимой и летом около 5 тыс. туристов в год, и заповедник продолжит работу по расширению и улучшению инфраструктуры. В 2019 г. планируется увеличить протяженность оборудованных троп и открыть новую выставочную экспозицию, посвященную саамам (Журналисты протестировали новый экомаршрут в Лапландском заповеднике, 2018).

В перспективе - создание кольцевого маршрута от Старой усадьбы заповедника с подъемом на гору Ельнюн I, переходом на гору Ельнюн II и спуском к Чунозерской усадьбе (отправной точке). Протяженность маршрута составит 14 км. Кроме того, планируется строительство нового Терема Деда Мороза, а на южной границе заповедника со временем будут построены лесные домики для проживания туристов (Сайт Лапландского природного заповедника, 2018).

В одном из самых северных в мире ботанических садов, Полярно-Альпийском ботаническом саду, созданы две экологические тропы для знакомства не только с местной флорой, но и с растительностью. Старейшая экологическая тропа Кольского полуострова проложена в середине 1930-х годов и была названа «Тропой географов». Этот познавательный пешеходный маршрут расположен на северо-восточном склоне горы Вудъяврчорр, давая возможность познакомить экскурсантов с представителями трех высотных поясов растительности Хибинских гор.

Экологическая тропа, которая поднимается практически на вершину горы Вудъяврчорр, проходит от смешанного таежного леса через березовое криволесье до гольцовых арктических пустынь на плоской вершине, откуда можно видеть прекрасные панорамы Хибин. А по пути экскурсанты знакомятся с уникальными растениями Кольского Севера.

Вторая экологическая тропа заложена на предгорной равнине в окрестностях г. Апатиты, на территории опытного участка ПАБСИ. Гордость апатитской площадки, что на подъезде к городу, на берегу Имандры, - дендрологическая коллекция северных и высокогорных видов, выполненная по географическому принципу и дополненная травянистыми растениями из тех же географических регионов. Пройдя по этому маршруту, экскурсанты знакомятся с растительностью Сибири, Северной Европы, Камчатки, гор Азии, Северной Америки, с редкими и охраняемыми видами из Красной книги России. Экологическая тропа начинает свой маршрут в сосновом лесу, проходит через дендрарий, потом по другим коллекциям древесных растений, а заканчивается на Щучьем озере, чьи окрестности богаты птицами, в том числе редкими для Кольского края (Кабыш, 2018). Сотрудникам ботанического сада требуется помощь добровольцев и волонтеров для традиционной подготовки экологических троп (обустройство, расчистка) к летнему туристическому сезону.

В заказнике «Сейдъявр» в 2016 г. волонтерами из разных регионов России была проложена двухкилометровая экологическая тропа в районе Сейдозера с туристическо-информационной навигацией и местами для отдыха, а в 2017 г. здесь была оборудована экотропа для людей с ограниченными возможностями здоровья. В этом труднодоступном районе Ловозерских тундр проходит популярный среди самодеятельных путешественников пешеходный туристический маршрут.

Любители пешего туризма в Кандалакшском районе могут выбрать четыре разноплановые экотропы: две эколого-краеведческие тропы - «Кандалакшский берег» и «Колвица», горная тропа на вершину горы Волостная и городская тропа здоровья. Трехкилометровый пешеходный маршрут «Кандалакшский берег», популярен среди местных жителей и туристов. Тропу обустроили в 2012 г., оборудовали указателями и табличками с описанием достопримечательностей. Начинается маршрут на Монастырском Наволоке в черте города, проходит вдоль Кандалакшского залива по 
верхней тропе скалы Барыня и заканчивается в живописной губе Питкуль. Здесь на полуострове сохранился памятник археологии - каменный лабиринт.

В селе Колвица (28 км от г. Кандалакша) для туристов оборудована экотропа к Колвицким водопадам протяженностью 2 км. Начало тропа берет от моста, далее идет по сосновому бору вдоль левого берега реки Колвица до водопада «Черный падун». На тропе таблички с информацией о природных объектах, на склонах оборудованы ступеньки. Тропа до сих пор дополняется новыми интересными объектами. В последнее время здесь была построена Никольская часовня, установлен Памятный камень с выбитой на нем историей с. Колвица, а на лесной тропе появился Лебедь-камень.

На горе Волосяной находится древнее капище, представляющее собой самое большое скопление священных камней саамов Сейда в Кандалакшском районе - более 200. Тропа начинается от сноупарка, что в 3-х км от города имеет протяженность почти 5 км, проходит по склону горы Волосяной до самой ее вершины, откуда открывается панорама на залив, город и окрестности. Высота горы - 475 м над уровнем моря. На середине маршрута в 2018 г. построен инновационный туристический приют - ДубльДом со всеми удобствами и панорамным окном. Тропу также используют в качестве трассы для скоростного спуска на горных велосипедах. Велосипедисты оборудовали маршрут деревянными мостками и трамплинами.

Городская «Тропа здоровья» начинается от навесного моста у гостиницы «Сполохи», проходит через сосновый лес по левому берегу реки Нива вверх по течению. Представляет собой пешеходную дорожку - терренкур, оборудованную местами для отдыха - скамейками и беседками. На тропе установлены информационные щиты и указатели, деревянные скульптуры и спортивные площадки. Изюминка тропы - белки, которых часто можно встретить здесь (Официальный сайт администрации Кандалакшского района, 2018)

В Терском районе в 2014 г. был реализован проект обустройства эколого-краеведческой тропы «Старинная поморская деревня Умба» протяженностью в 5.5 км. Проект стал победителем всероссийского конкурса проектов «Культурная мозаика малых городов и сел» фонда Тимченко в номинации «Пространство Жизни» и получил грант на реализацию идеи. Тропа начинается у моста через р. Умба, далее тропа проходит через историческую часть поморского поселка Умба (Старая Умба) вдоль правого берега реки к месту впадения ее в Белое море. По всему пешеходному маршруту местными волонтерами и юными экологами были установлены информационные щиты об истории поморского поселения, традиционных промыслах, флоре и фауне Терского берега. Также были оборудованы стоянки для отдыха туристов со смотровой площадкой. По тропе ежегодно проходит от 3 до 4 тыс. туристов (Эколого-краеведческая тропа «Старинная деревня Умба» откроется на юге Заполярья, 2014).

В Терском районе также планируют обустроить пешеходный маршрут к петроглифам на островах озера Канозеро. Уникальному археологическому комплексу планируется присвоить статус объекта всемирного наследия Юнеско, Канозерские петроглифы находятся в одном из самых труднодоступных мест Кольского Севера, попасть к ним сейчас можно только на лодке или вездеходе. Музейный проект музея под открытым небом «Петроглифы Канозера» - «Пешком в каменный век» стал победителем грантового конкурса «Музеи Русского Севера». Полученные средства пойдут на поиск инвестора и на обустройство экологической тропы протяженностью 18-20 км от автодороги Умба-Кандалакша до кордона на западном берегу Канозера. Через болотистый участок длиной 5 км будут проложены деревянные настилы и мосты. Тропа будет доступна и для велотуристов, планируется установить на маршруте информационные щиты, указатели и места для отдыха (Сайт музея наскального исскуства «Петроглицы Канозера, 2018).

В ближайшее время будут оборудованы пешеходные туристические маршруты в созданных ООПТ: в национальном парке «Хибины», природном парке на полуостровах Средний и Рыбачий. Будет увеличиваться количество информационных стендов, аншлагов, костровищ, мест для уборки мусора с целью комфортного пребывания туристов на ООПТ.

Инновационным направлением в развитии экологического туризма на Кольском Севере может стать организация национальной пешеходной тропы. Национальные тропы - маршруты массо- 
вого пешеходного туризма, получившие большую популярность во всем мире, кроме России. Можно предложить организовать такую тропу на территории Хибин и Ловозерских тундр. Национальная пешеходная тропа должна быть протяженной, обустроенной, общедоступной для всех слоев населения и бесплатной для посещения. Тропу должны проложить опытные туристы и волонтеры по грунтовым дорожкам с заходом в наиболее красивые и интересные места региона.

\section{Литература}

1. Журналисты протестировали новый экомаршрут в Лапландском заповеднике [Электронный ресурс]. Режим доступа: https://www.murman.ru/news/2018/12/26/0749 (дата обращения: 15.11.2018).

2. Кабыш 3. В Радость и на пользу // Мурманский Вестник. 2018. 1 июня. С. 5.

3. Калинина Л. В Лапландском заповеднике открыта новая экологическая тропа [Электронный ресурс]. Режим доступа: http://kn51.ru/news/society/ecology/2017/10/02/v-laplandskom-zapovednike-otkryta-novayaekologicheskaya-tropa.html (дата обращения: 15.11.2018).

4. Официальный. сайт администрации Кандалакшского района. Туризм. Туристские тропы. [Электронный pecypc]. Режим доступа: http://www.kandalaksha-admin.ru/index.php/index.php?option=com_content\&view= article\&id=9223\#p04 (дата обращения: 12.11.2018).

5. Сайт заповедника «Пасвик» [Электронный ресурс]. Режим доступа: http://www.pasvik51.ru/index.php/ru/ (дата обращения: 12.11.2018).

6. Сайт Лапландского природного заповедника [Электронный ресурс]. Режим доступа: http://www. laplandzap.ru/ (дата обращения: 22.11.2018).

7. Сайт музея наскального исскуства «Петроглицы Канозера» [Электронный ресурс]. Режим доступа: http:// kanozero.murm.muzkult.ru/ (дата обращения: 16.11.2018).

8. Чижова, В.П. Рекреационные ландшафты: устойчивость, нормирование, управление / В.П. Чижова. Смоленск: Ойкумена. 2011. 176 с.

9. Чижова, В.П. Школа природы. Экологическое образование в охраняемых природных территориях. М.: Эколого-просветительский центр «Заповедники» - WWF. 1997. 128 с.

10. Эколого-краеведческая тропа «Старинная деревня Умба» откроется на юге Заполярья // Мурманский вестник. 2014. 13 октября. 